\title{
Potent inhibition of rhabdoid tumor cells by combination of flavopiridol and $4 \mathrm{OH}$-tamoxifen
}

\author{
Velasco Cimica ${ }^{1 \dagger}$, Melissa E Smith ${ }^{1 \dagger}$, Zhikai Zhang ${ }^{1}$, Deepti Mathur ${ }^{1}$, Sridhar Mani ${ }^{1,2,3}$, Ganjam V Kalpana ${ }^{1,3^{*}}$
}

\begin{abstract}
Background: Rhabdoid Tumors (RTs) are highly aggressive pediatric malignancies with poor prognosis. There are currently no standard or effective treatments for RTs in part because treatments are not designed to specifically target these tumors. Our previous studies indicated that targeting the cyclin/cdk pathway is a novel therapeutic strategy for RTs and that a pan-cdk inhibitor, flavopiridol, inhibits RT growth. Since the toxicities and narrow window of activity associated with flavopiridol may limit its clinical use, we tested the effect of combining flavopiridol with 4-hydroxy-Tamoxifen $(4 \mathrm{OH}-T a m)$ in order to reduce the concentration of flavopiridol needed for inhibition of RTs.

Methods: The effects of flavopiridol, $4 \mathrm{OH}-\mathrm{Tam}$, and their combination on RT cell cycle regulation and apoptosis were assessed by: i) cell survival assays, ii) FACS analysis, iii) caspase activity assays, and iv) immunoblot analysis. Furthermore, the role of p53 in flavopiridol- and $4 \mathrm{OH}$-Tam-mediated induction of cell cycle arrest and apoptosis was characterized using RNA interference (siRNA) analysis. The effect of p53 on flavopiridol-mediated induction of caspases 2, 3, 8 and 9 was also determined.

Results: We found that the combination of flavopiridol and $4 \mathrm{OH}$-Tam potently inhibited the growth of RT cells. Low nanomolar concentrations of flavopiridol induced $G_{2}$ arrest, which was correlated to down-modulation of cyclin B1 and up-regulation of p53. Addition of $4 \mathrm{OH}$-Tam did not affect flavopiridol-mediated $\mathrm{G}_{2}$ arrest, but enhanced caspase 3,7-mediated apoptosis induced by the drug. Abrogation of p53 by siRNA abolished flavopiridolinduced $\mathrm{G}_{2}$ arrest, but enhanced flavopiridol- (but not 4OH-Tam-) mediated apoptosis, by enhancing caspase 2 and 3 activities.

Conclusions: Combining flavopiridol with $4 \mathrm{OH}$-Tam potently inhibited the growth of RT cells by increasing the ability of either drug alone to induce caspases 2 and 3 thereby causing apoptosis. The potency of flavopiridol was enhanced by abrogation of p53. Our results warrant further studies investigating the combinatorial effects of flavopiridol and $4 \mathrm{OH}-$ Tam as a novel therapeutic strategy for RTs and other tumors that have been shown to respond to flavopiridol.
\end{abstract}

\section{Background}

RTs, including Malignant Rhabdoid Tumors (MRT), Atypical Teratoid and Rhabdoid Tumors (AT/RT), and extra renal rhabdoid tumors (ERRT) are rare, but highly aggressive pediatric solid tumors with poor prognosis [1]. Current therapy for RTs includes surgical resection, radiation therapy, and/or chemotherapy with empirically selected and highly toxic chemotherapeutics, which are

\footnotetext{
* Correspondence: ganjam.kalpana@einstein.yu.edu

† Contributed equally

'Department of Genetics, Albert Einstein College of Medicine, 1300 Morris

Park Avenue, Bronx, New York 10461 USA

Full list of author information is available at the end of the article
}

largely ineffective [2,3]. Despite aggressive treatment, mean survival with surgical intervention alone is only 3 months and with adjuvant chemotherapy and radiotherapy is only 8 months [4]. Therefore, strategies based on understanding the genesis of RTs will aid in the development of novel therapies. RTs are characterized by biallelic deletions and/or mutations in INI1/hSNF5, a tumor suppressor and component of the chromatin remodeling SWI/SNF complex [5,6]. Reintroduction of INI1/hSNF5 into RT cells induces $G_{1}$ cell cycle arrest and senescence. INI1/hSNF5 mediates these effects by directly activating $\mathrm{p} 16^{\text {Ink4a }}$ by recruiting the SWI/SNF complex and by directly repressing cyclin $D 1$ by

\section{() Biomed Central}


recruiting the HDAC1 complex [7-10]. We have found that cyclin D1 is de-repressed in human and mouse RTs and is required for rhabdoid tumorigenesis in mouse models $[9,11,12]$. Such studies indicated that therapeutic targeting of cyclin D1 and its pathway could be an effective and novel therapeutic strategy for RTs.

We previously reported that down-modulating cyclin D1 and inhibiting cyclin dependent kinases (cdks) using either flavopiridol or a combination of $N$-(4-hydroxyphenyl)retinamide (4-HPR) with $4 \mathrm{OH}$-Tam is effective in inhibiting RTs in vitro and in xenograft tumor models in vivo [11,13]. The effectiveness of 4-HPR and flavopiridol was correlated with down-modulation of cyclin D1 in xenograft tumors [13].

Flavopiridol is one of the first cdk inhibitors to enter clinical trials. Although early clinical trials were unsuccessful, design of a novel schedule of administration based on the in vitro and in vivo pharmacokinetic modeling of flavopiridol's effect has shown promising efficacy in refractory chronic lymphocytic leukemia [14]. Phase I trials of flavopiridol in children have revealed that its toxicity profile, pharmacokinetics, and maximum tolerable dose were similar to that in adults, indicating that using flavopiridol in RT patients, a largely pediatric population, is feasible [15].

The effects of flavopiridol on cancer cells are varied and cell type dependent. In many cell lines flavopiridol leads to $G_{1}$ arrest due to down-modulation of cyclin D1 and inhibition of its pathway by various mechanisms [16-24]. In other cells, flavopiridol induces $G_{2}$ arrest, in part due to its potent ability to inhibit cdk 7, 8 and 9 activities [25]. Flavopiridol also inhibits transcription of Mdm-2 resulting in the accumulation of its proteolytic target, p53, which triggers p21 Waf1 $u$ u-regulation, cyclin $B 1$ down-regulation, and ultimately $G_{2}$ arrest [26]. Flavopiridol can induce apoptosis at nanomolar concentrations and its pro-apoptotic action is either caspasedependent or -independent [25]. Flavopiridol can trigger apoptosis by activation of caspases 2,3 and 8 [27] or by activation of apoptosis inducing factor (AIF) via its release from the mitochondria [28]. At this point, the mechanism of action of flavopiridol in RT cells is not completely understood.

Since flavopiridol can be toxic at high doses, recent studies have focused on combining low concentrations of flavopiridol with other anti-neoplastic agents $[29,30]$. In this report, we tested the combination of flavopiridol with $4 \mathrm{OH}$-Tam to determine its ability to increase therapeutic efficacy against RT cells. $4 \mathrm{OH}-\mathrm{Tam}$ inhibits tumor cell growth in part by deregulating cyclins and cdks. Breast cancer cells over-expressing cyclin D1 are resistant to $4 \mathrm{OH}-\mathrm{Tam}$ and the level of cyclin $\mathrm{D} 1$ is negatively correlated to responsiveness to $4 \mathrm{OH}-\mathrm{Tam}$ [31-34]. 4OH-Tam suppresses the growth of estrogen- receptor positive tumors by down-modulating cyclin D1 [35]. Furthermore, treatment of tumor cell lines with $10 \mu \mathrm{M} 4 \mathrm{OH}-\mathrm{Tam}$ induces the expression of $\mathrm{p} 21^{\text {Waf1 }}$ and p27 ${ }^{\text {Kip1 }}$, which are known to block the effects of cyclin D1 [36]. Previous studies have demonstrated that $4 \mathrm{OH}-$ Tam is effective in inducing cytotoxic effects in RT cells [37]. In this study it was demonstrated that the expression of ER $\alpha$ receptor in RT cells is variable and that the cytotoxic effects of $4 \mathrm{OH}-\mathrm{Tam}$ are independent of ER $\alpha$ expression [37]. Since the efficacy of flavopiridol in xenograft RTs was correlated with down-modulation of cyclin D1 and up-regulation of p21 ${ }^{\text {Waf1 }}$ [13], we considered combining $4 \mathrm{OH}$-Tam with flavopiridol to enhance its therapeutic efficacy in RT cells.

We report here that the combination of flavopiridol with $4 \mathrm{OH}-\mathrm{Tam}$ potently inhibited the survival of RT cells. A low concentration of flavopiridol (100 nM) induced $G_{2}$ arrest in RT cells in a p53-dependent manner and resulted in a moderate amount of apoptosis. Addition of $4 \mathrm{OH}-\mathrm{Tam}$ significantly increased flavopiridol-mediated apoptosis. Down-modulation of p53 did not affect $4 \mathrm{OH}-\mathrm{Tam}$-induced cytotoxicity, but significantly enhanced flavopiridol-mediated apoptosis. Furthermore, we found that the increased cytotoxic effects of flavopiridol and 4OH-Tam correlated with augmentation of caspase 2 and 3 activities and that these effects were independent of p53. These studies indicate that the combination of flavopiridol and $4 \mathrm{OH}-$ Tam can be effective in potently inhibiting RT cell growth and is potentially a novel therapeutic strategy against RTs.

\section{Methods}

\section{Cell culture and drug treatment}

MON [6], G401 (American Type Culture Collection), and A204 cells (American Type Culture Collection) were maintained in RPMI supplemented with $10 \%$ fetal bovine serum, $50 \mathrm{U} / \mathrm{ml}$ penicillin, $50 \mu \mathrm{g} / \mathrm{ml}$ streptomycin, and $2 \mathrm{mM} \mathrm{L}$-glutamine. For drug studies, the cells were transferred one day before drug treatment to RPMI containing 10\% charcoal and dextran treated fetal bovine serum (HyClone, Cat. SH30068.03). Flavopiridol was obtained from the CTEP program at NCI (courtesy of Dr. Colevas). 4OH-Tam and pan-caspase inhibitor z-VAD-FMK were purchased from SIGMA (Catalogue \#H7904) and Promega (Catalogue \#G7232) respectively.

\section{Cell Survival analysis}

8,000 cells/well (MON and A204) or 6,500 cells/well (G401) were plated in 96-well plates and treated with different concentrations/combinations of drugs, using the epMotion 5070 automated liquid handler system (Eppendorf). The CellTiter 96 AQueous One Solution Cell Proliferation Assay was used to determine cell 
survival (Promega, Catalogue \#G3580). Data elaboration of cell survival, $\mathrm{IC}_{50}$, and drug combination effects were performed according to previously described methods [11].

\section{FACS Analysis}

Propidium iodide staining and FACS analysis were performed as described previously [9]. Annexin staining was performed using Annexin V-FITCH Apoptosis Detection Kit I (BD Pharmingen Catalogue \#556547) according to the manufacturer's instructions. Data was elaborated using CellQuest Pro program (BD Pharmingen).

\section{Statistical analysis}

Data was analyzed using GraphPad Prism by applying the ANOVA test or t-test.

\section{Immunoblot analysis}

Immunoblot analysis was carried out as described previously with minor modifications [9]. Dry milk was used as a blocking agent for the following antibodies: p53 (Santa Cruz Catalogue \#sc-126), cyclin A (Santa Cruz Catalogue \#sc-239), cyclin B1 (Santa Cruz Catalogue \#sc-752), cyclin E (LabVision Catalogue \#MS-870-P), cyclin D1 (Lab Vision Catalogue \#RB-010-P), E2F-1 (Santa Cruz Catalogue \#sc-251), GAPDH (Chemicon Catalogue \#MAB374) and Rb (Santa Cruz Catalogue \#sc-102); and bovine serum albumin for the following antibodies: cdk 2 (Santa Cruz Catalogue \#sc-163), cdk 4 (Santa Cruz Catalogue \#sc-260), cdk 6 (Santa Cruz Catalogue \#sc-7961) and p21 (Calbiochem Catalogue \#OP64). Chemiluminescence detection was achieved using SuperSignal West Pico Chemiluminescence Substrate (Pierce Catalogue \#34080).

\section{RNA interference}

MON cells were plated at 300,000 cells/well in 6-well plates one day before transfection. Cells were transfected using DharmaFECT siRNA transfection reagent (Dharmacon Catalogue \#T-200(01-07)-01) according to the manufacturer's instruction and using previously published p53 siRNA (Qiagen Catalogue \#024849) and control (Cy3-Luciferase GL2 Duplex, Dharmacon Catalogue \#D-001110-01-05). One day post-transfection, cells were split into 50,000 cells/well using medium containing $10 \%$ charcoal and dextran treated fetal bovine serum, for drug treatment the following day.

\section{Immunocytochemistry}

MON cells were grown on glass coverslips and treated with drugs. Cells were fixed with $4 \%$ paraformaldehydePBS solution for 10 minutes, and permeabilized with $0.1 \%$ triton-PBS solution for 10 minutes. Cover-slips were treated for 1 hour at room temperature with 1:250 diluted $\alpha$ p21 antibody (Calbiochem Catalogue \#OP64). Staining was detected using the Vectastain $A B C$ kit (Vector Laboratories Catalogue \#PK-6102) according to manufacturer's instruction. Peroxidase staining was developed using the DAB enhanced liquid substrate system (SIGMA Catalogue \#D3939-1SET). The percentage of cells with nuclear expression of p21 was quantified by counting 250 to 300 individual cells, noting whether or not their nuclei showed positive staining above the background. The background staining was defined as an intensity of staining at or below the intensity of the negative control (i.e. any background staining that occurred in the absence of a p21-specific antibody).

\section{Caspase-profiling assays}

Caspase 3/7 Assay was performed using the Caspase-Glo 3/7 Assay kit (Promega Catalogue \#G8093). Caspase activity profiling assays were performed using ApoAlert Caspase Profiling Plate (Clontech Catalogue \#630225), according to the manufactures' instruction with minor modification, using $50 \mu \mathrm{g}$ of protein for each well of the assay.

\section{Results and Discussion}

\section{Combination treatment with flavopiridol and 40H-Tam} inhibits the growth of RT cells

To determine the effect of combining flavopiridol with 4OH-Tam, we treated MON, G401, and A204 RT cells with increasing concentrations of flavopiridol (0 to 200 $\mathrm{nM}$ ) in combination with $2.5,5.0$, or $10.0 \mu \mathrm{M} 4 \mathrm{OH}-$ Tam for two days. Flavopiridol inhibited RT cell growth with $\mathrm{IC}_{50}$ values of $\sim 50-100 \mathrm{nM}$, with MON cells showing an intermediate level of sensitivity compared to G401 and A204 cells (Figure 1A-D). Exposure of all cells to flavopiridol and $4 \mathrm{OH}-\mathrm{Tam}$ in combination resulted in a dramatic reduction in $\mathrm{IC}_{50}$ values, with 10 $\mu \mathrm{M} 4 \mathrm{OH}-\mathrm{Tam}$ reducing the $\mathrm{IC}_{50} \mathrm{~s}$ to $\sim 0.12-0.2 \mathrm{nM}$ (Figure 1A-D). Furthermore, increasing the time of exposure to the combination of drugs enhanced the inhibitory effects in both MON and G401 cells (compare Figures $1 \mathrm{~A}$ and $1 \mathrm{~B}$ with Figure $2 \mathrm{~A}, \mathrm{~B}, \mathrm{E}$, and $2 \mathrm{~F}$ ). Bar graphs derived from the data in Figure $2 \mathrm{~A}$ and $2 \mathrm{E}$ are given to show the decreases in cell survival induced by the specific concentrations of the drugs after three days of exposure (Figure 2D and $2 \mathrm{H}$ ). We also tested the effect of $4 \mathrm{OH}-\mathrm{Tam}$ alone and found that $4 \mathrm{OH}$-Tam decreased cell survival significantly (Figure $2 \mathrm{C}$ and $2 \mathrm{G}$ ). However, increasing time of exposure to $4 \mathrm{OH}-\mathrm{Tam}$ alone from one to three or five days, did not result in further decreases of cell survival (Figure $2 \mathrm{C}$ and 2G). Thus, while the flavopiridol and $4 \mathrm{OH}-\mathrm{Tam}$ combination resulted in a time dependent decrease of survival, the effect of $4 \mathrm{OH}$-Tam alone was independent of time of 

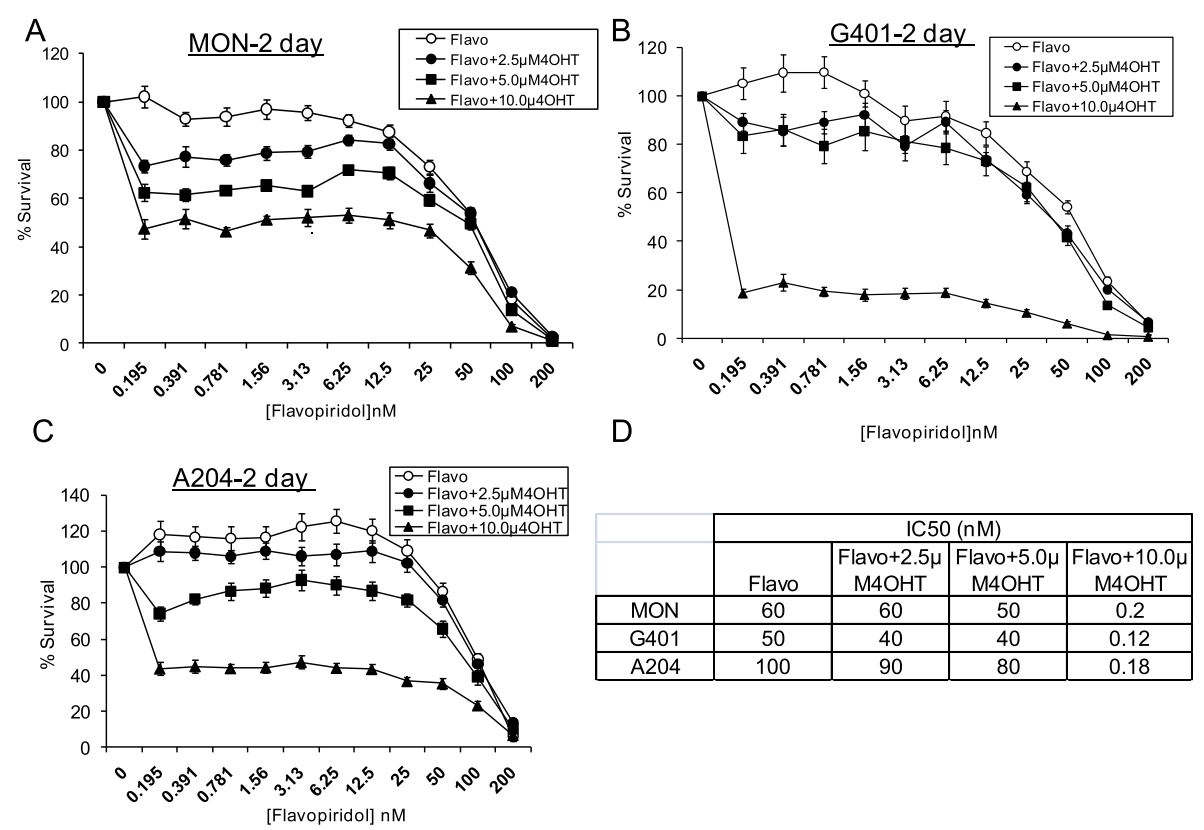

Figure 1 Inhibition of rhabdoid tumor growth by flavopiridol and $\mathbf{4 O H}-\mathbf{T a m}$. A-C. Survival curves of MON (A), G401 (B), and A204 (C) cells treated with flavopiridol in the presence and absence of $4 \mathrm{OH}$-Tam for two days. D. Table of IC50 values as approximated from A-C. Flavo = flavopiridol; $4 \mathrm{OHT}=4 \mathrm{OH}-\mathrm{Tam}$.

exposure. Notably, by day five of treatment, combinations of very low concentrations of flavopiridol $(\sim 0.2$ $\mathrm{nM}$ ) and $10 \mu \mathrm{M} 4 \mathrm{OH}-\mathrm{Tam}$ decreased cell survival by $80 \%$ in MON and $99 \%$ in G401 cells (Figure 2B and 2F). These results indicated that treatment with low concentrations of flavopiridol in combination with $4 \mathrm{OH}-\mathrm{Tam}$ for prolonged periods potently inhibits RT cell growth.

\section{Induction of apoptosis by flavopiridol and $4 \mathrm{OH}-\mathrm{Tam}$}

To determine the mechanism of growth inhibition by these drugs, we studied MON cells which showed intermediate responses to the combination of drugs with an intermediate level of $4 \mathrm{OH}$-Tam $(5 \mu \mathrm{M})$ and duration of treatment. MON cells were exposed to combinations of flavopiridol and $5 \mu \mathrm{M} 4 \mathrm{OH}-\mathrm{Tam}$ for two days and subjected to cell cycle analysis. Treatment of cells with $5 \mu \mathrm{M} 4 \mathrm{OH}$-Tam alone resulted in $\mathrm{G}_{1}$ arrest $(p=0.0117$, Figure $3 \mathrm{~A}$ ). Our previous results indicated that flavopiridol at 200-400 $\mathrm{nM}$ induces $\mathrm{G}_{1}$ arrest [13]. However, treatment with $100 \mathrm{nM}$ flavopiridol induced $\mathrm{G}_{2}$ arrest in the presence or absence of $4 \mathrm{OH}-\mathrm{Tam}(p=0.0039$ and $p=0.0003$, respectively, Figure $3 \mathrm{~A}$ ) indicating that the stage of cell cycle arrest induced is dose-dependent. These results also indicate that $G_{2}$ arrest induced by flavopiridol is dominant over $4 \mathrm{OH}$-Tam-induced $\mathrm{G}_{1}$ arrest. Analysis of the sub- $G_{1}$ fraction of cells after single or combination treatment indicated that the percentage of sub- $G_{1}$ cells increased in a dose-dependent manner upon treatment with flavopiridol, which was further enhanced by combination with $4 \mathrm{OH}$-Tam (Figure 3B). Very high levels of cell death are induced by these treatments and this likely plays the major role, compared to induction of cell cycle arrest, in inducing cytotoxicity in response to treatment with these drugs. To determine if cell death was due to apoptosis, the cells were stained for annexin (indicative of apoptosis) and propidium iodide (indicative of necrosis) and the percentage of cells positive for either or both stains was determined by FACS (Figure 3C). While the percentage of necrotic or dead cells remained largely unchanged, there was a dose-dependent increase in annexin-positive cells demonstrating that combination treatment with flavopiridol and $4 \mathrm{OH}-\mathrm{Tam}$ induces significant levels of apoptosis.

\section{Induction of apoptosis by flavopiridol and $4 \mathrm{OH}-\mathrm{Tam}$ is caspase-dependent}

Since it is known that flavopiridol can induce apoptosis by caspase-dependent or caspase-independent mechanisms, we investigated the effect of a caspase inhibitor on drug-induced cytotoxicity. MON cells were exposed for two days to flavopiridol and $4 \mathrm{OH}$-Tam in the presence or absence of the pan-caspase inhibitor, Z-VAD-FMK, and FACS analysis was carried out to assess the effects on cell cycle and apoptosis. The results indicated that drug-induced cell cycle arrest was unaffected $(p=$ 0.0458 and $p=0.0025$ for G1-arrest induced by $100 \mathrm{nM}$ flavopiridol with and without $4 \mathrm{OH}-\mathrm{Tam}$ respectively) 


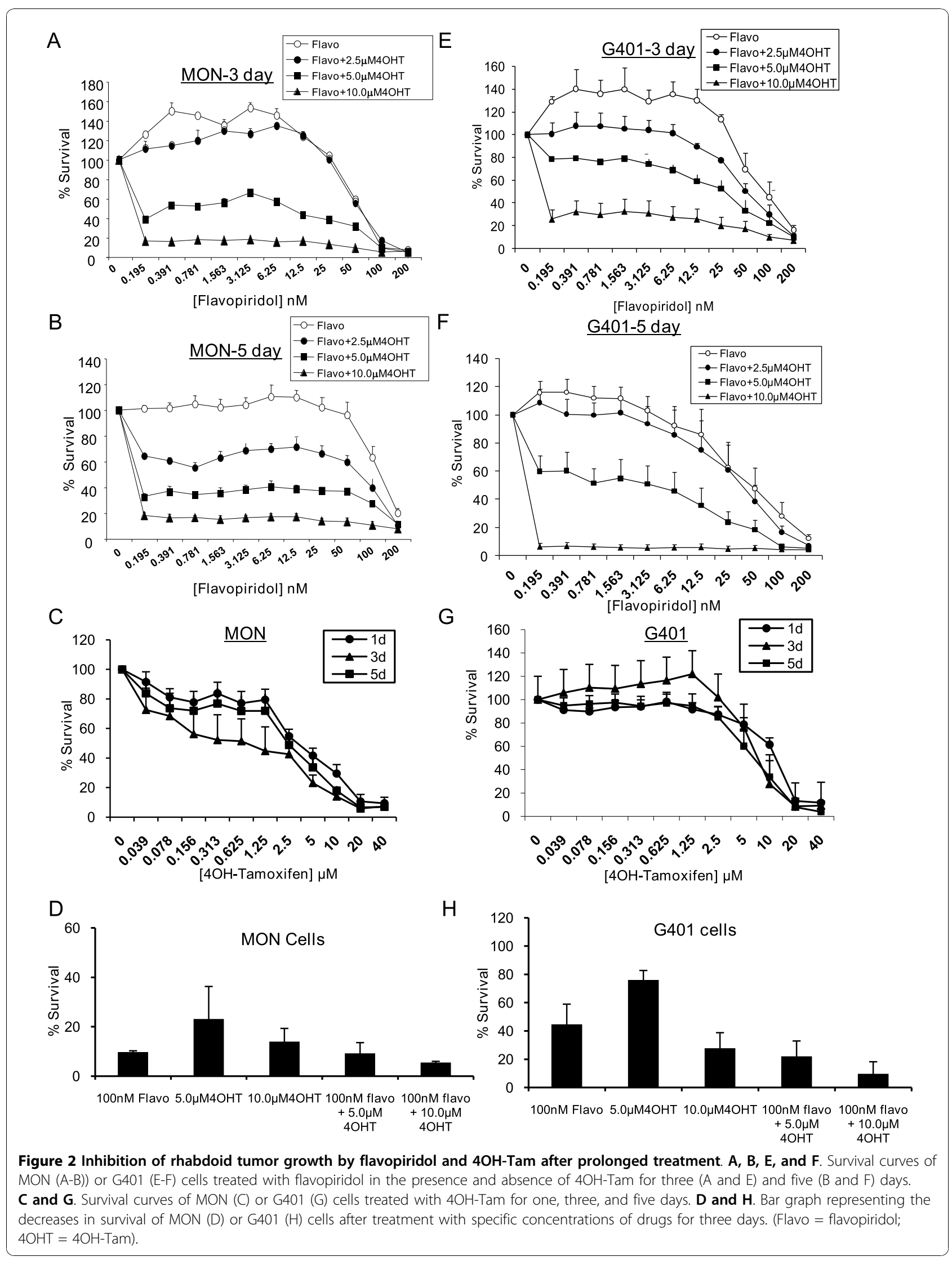




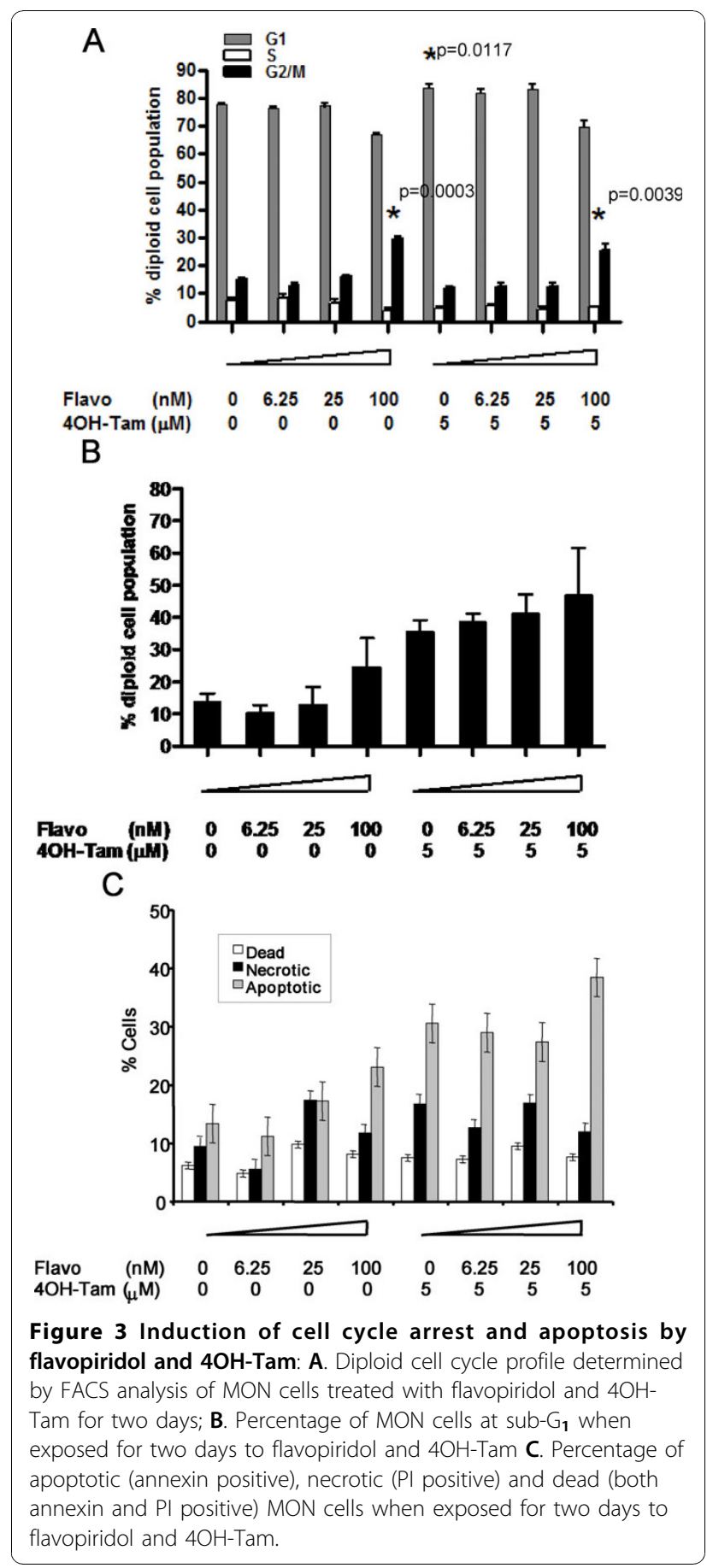

(Figure 4A), but induction of apoptosis by flavopiridol with or without $4 \mathrm{OH}-\mathrm{Tam}$ was significantly inhibited by Z-VAD-FMK $(p<0.0001$, Figure $4 \mathrm{~B})$. This established that cell death induced by flavopiridol, $4 \mathrm{OH}-\mathrm{Tam}$, or their combination is mediated by caspase-dependent apoptosis in RT cells. We further investigated the kinetics of induction of caspase 3 and 7 activities upon drug treatment. The results indicated that, while

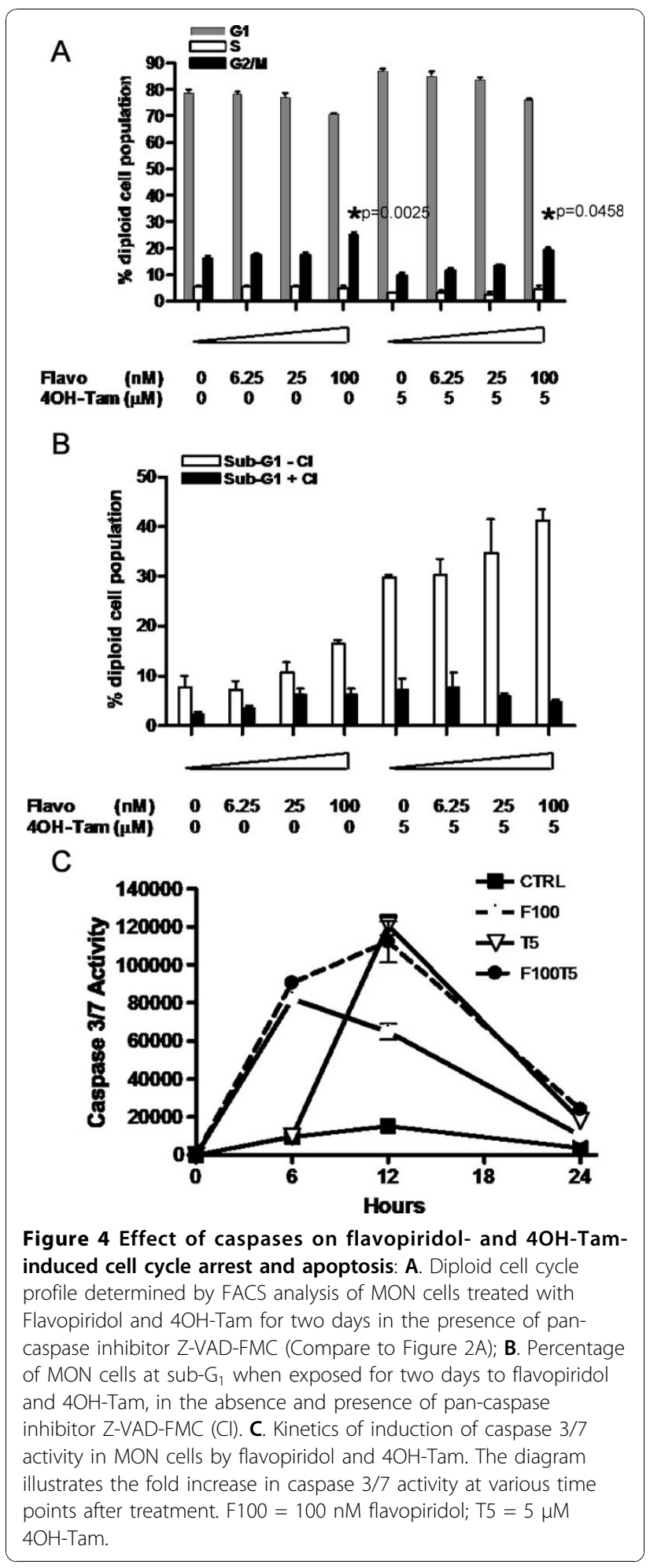

flavopiridol induced peak caspase 3 and 7 activities at six hours, 4OH-Tam exhibited delayed kinetics with peak induction at 12 hours. Interestingly, combination of $4 \mathrm{OH}-\mathrm{Tam}$ and flavopiridol elevated caspase 3 and 7 
activities at both 6 and 12 hours (Figure 4C). These results suggest that combination of flavopiridol and $4 \mathrm{OH}-\mathrm{Tam}$ could increase apoptosis by inducing and prolonging caspase $3 / 7$ activities.

\section{Mechanism of $G_{2}$ arrest mediated by flavopiridol and 4OH-Tam}

To determine the mechanism of cell cycle arrest induced by flavopiridol and $4 \mathrm{OH}-\mathrm{Tam}$, we examined the expression levels of several cell cycle regulatory and tumor suppressor proteins in the presence and absence of drugs. $100 \mathrm{nM}$ flavopiridol induced $\mathrm{p} 53$ and p21 ${ }^{\text {Waf-1 }}$ and repressed cyclin B1, consistent with the observed
$\mathrm{G}_{2}$ arrest (Figure $5 \mathrm{~A}$ ). We found that the majority of cyclins and cdks, including cyclins D1, A and E, and cdks 2,4 and 6 were unaffected by concentrations of flavopiridol $\leq 100 \mathrm{nM}$ (Figure 5A). Interestingly, the presence of $4 \mathrm{OH}-\mathrm{Tam}$ did not significantly alter the effects of flavopiridol on cyclin and cdk expression, but further decreased the level of $\mathrm{pRb}$ protein and phosphorylation (Figure 5A compare lanes 4 and 8). We also observed differential effects on $\mathrm{pRb}$ phosphorylation. Concentrations of flavopiridol $\leq 25 \mathrm{nM}$ increased the level of phosphorylated pRb (Figure 5A lanes 2 and 3), but 100 $\mathrm{nM}$ dramatically decreased the phosphorylated form of $\mathrm{pRb}$ (Figure 5A lane 4). Addition of 4OH-Tam

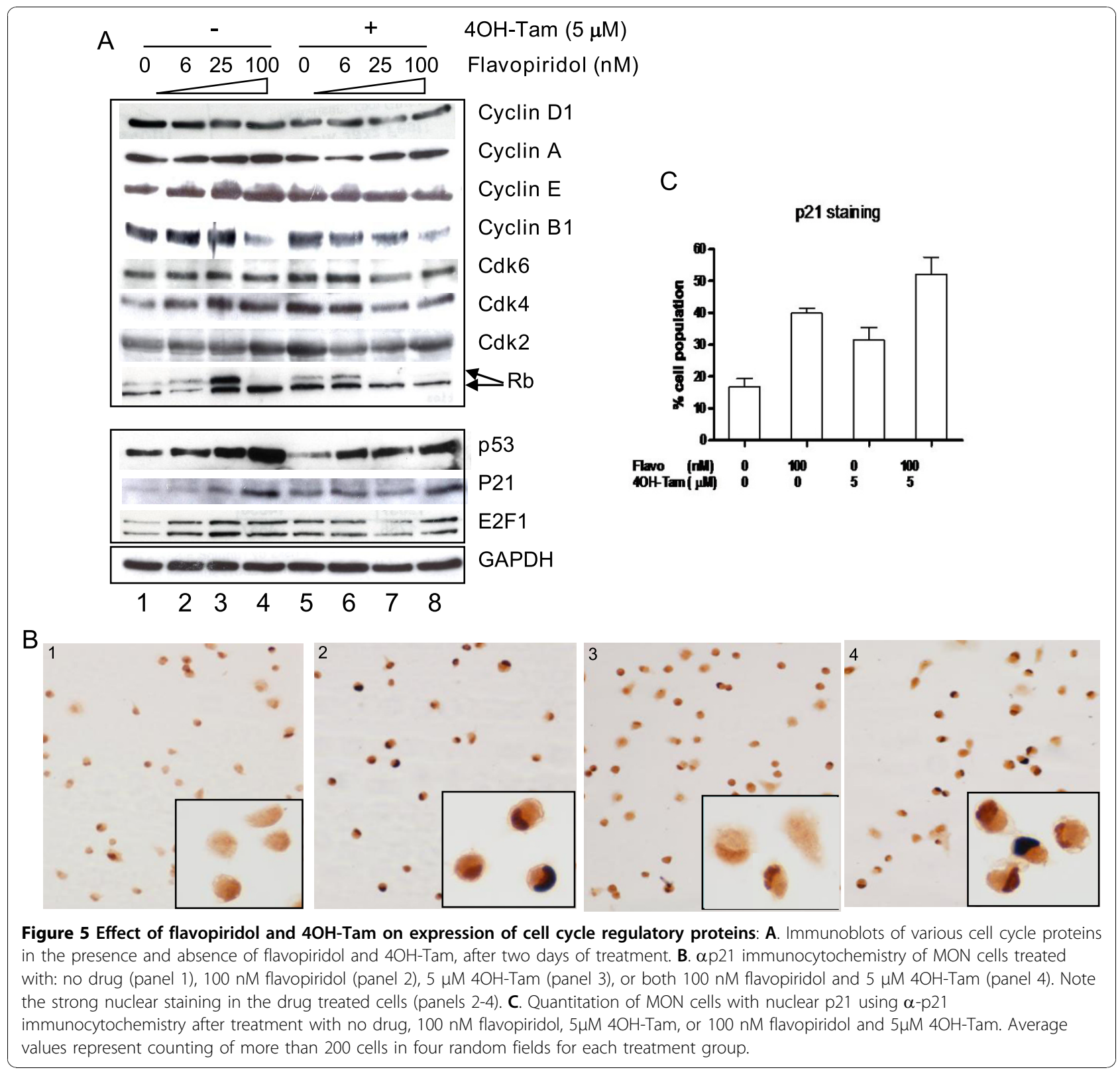


eliminated the flavopiridiol-induced phosphorylation of $\mathrm{pRb}$ at the $25 \mathrm{nM}$ concentration (Figure 5A lane 7). However, 4OH-Tam had no effect on $100 \mathrm{nM}$ flavopiridol-induced inhibition of $\mathrm{pRB}$ phosphorylation, consistent with the observed dominant effect of $100 \mathrm{nM}$ flavopiridol in inducing $G_{2}$ arrest.

\section{Flavopiridol induced p2 $1^{\text {Waf-1 }}$ expression in RT cells}

Our previous analysis indicated that flavopiridol efficacy in mouse xenografts correlated to both down-modulation of cyclin D1 and up-regulation of $\mathrm{p} 21^{\text {Waf-1 }}$ [13]. Therefore, we examined p $21^{\text {Waf-1 }}$ levels upon flavopiridol treatment with and without $4 \mathrm{OH}-\mathrm{Tam}$. We found that $\mathrm{p} 21^{\mathrm{Waf}-1}$ was up-regulated in a dose-dependent manner upon treatment with flavopiridol (Figure 5A, lanes 1-4), but 4OH-Tam alone only modestly up-regulated $\mathrm{p} 21^{\mathrm{Waf}-1}$ (Figure 5A, compare lanes 1 and 5). We also investigated the accumulation of nuclear $\mathrm{p} 21^{\text {Waf-1 }}$ upon drug treatment by immunocytochemical analysis. The results indicated that flavopiridol treatment led to increased nuclear $\mathrm{p} 21^{\mathrm{Waf}-1}$, which was further increased upon addition of $4 \mathrm{OH}-\mathrm{Tam}$ (Figure $5 \mathrm{~B}$ and $5 \mathrm{C}$ ). These results were confirmed by quantifying the percentage of cells with nuclear p21 Waf-1 (Figure 5C) and, taken together, indicate that combination treatment results in both increased protein levels and increased nuclear localization of $\mathrm{p} 21^{\text {Waf- }-1}$.

\section{Abrogation of p53 inhibited cell cycle arrest but enhanced apoptosis induced by flavopiridol}

The above studies pointed to the involvement of $\mathrm{p} 21^{\text {Waf- } 1}$ in flavopiridol or flavopiridol plus $4 \mathrm{OH}$-Tam-mediated cytotoxicity. It has been established that $\mathrm{p} 21^{\text {Waf-1 }}$ is a downstream effector of p53 [38]. Furthermore, tumorigenesis in Ini1 heterozygous mice is enhanced upon abrogation of p53 [39]. Since p53 is up regulated upon flavopiridol treatment, we further investigated its role. To determine whether p53 is necessary for flavopiridolinduced cell cycle arrest and/or apoptosis, RNA interference was used to down-modulate p53 expression. Transfection of RT cells with p53 siRNA slightly enhanced cell proliferation (data not shown). As expected, flavopiridol markedly increased p53 expression in cells transfected with control siRNA (Cy3), but not in cells transfected with p53 siRNA (Figure 6A, compare lanes 2 and 6). FACS analysis of cells transfected with control or p53 siRNA and treated with single or combination drugs for two days indicated that, while control siRNA did not affect drug-induced cell cycle arrest $(\mathrm{p}=0.0221$ and $\mathrm{p}=$ 0.0035 for $\mathrm{G}_{1}$-arrest induced by $100 \mathrm{nM}$ flavopiridol with and without 4-OH-Tam respectively, Figure 6B), knockdown of p53 resulted in abrogation of flavopiridolmediated $\mathrm{G}_{2}$ arrest both in the presence and absence of $4 \mathrm{OH}-\mathrm{Tam}(\mathrm{p}=1.000$ (not significant), Figure $6 \mathrm{C}$ ). These results indicated that p53 is necessary for flavopiridolmediated $\mathrm{G}_{2}$ arrest in RT cells.

Interestingly, knock-down of p53 demonstrated differential effects on flavopiridol and 4OH-Tam-mediated apoptosis in RT cells. Knock-down of p53 had no effect on $4 \mathrm{OH}-\mathrm{Tam}$-induced apoptosis indicating that $4 \mathrm{OH}-$ Tam-induced apoptosis is independent of p53 (Figure 6D). However, p53-knockdown enhanced flavopiridolmediated apoptosis in the presence or absence of $4 \mathrm{OH}$ Tam (Figure 6D). These results indicated that p53 is detrimental to flavopiridol-induced apoptosis in MON cells. Additionally, these results indicated that flavopiridol and $4 \mathrm{OH}-\mathrm{Tam}$ induce apoptosis in RT cells by two different mechanisms; flavopiridol-mediated apoptosis being inhibited by $\mathrm{p} 53$ and $4 \mathrm{OH}-\mathrm{Tam}$-induced apoptosis being independent of $\mathrm{p} 53$.

\section{Role of caspases in flavopiridol and $40 \mathrm{H}-\mathrm{Tam}$ induced apoptosis}

Expression of p53 has been associated with resistance to radiation-induced apoptosis in some cancers including gliomas and keratinomas [40,41]. Many RTs are resistant to chemotherapy and radiotherapy; however the mechanistic basis for this resistance is not clearly understood $[42,43]$. Based on our results we surmised that induction of $\mathrm{p} 53$ by flavopiridol is counter-productive to induction of apoptosis in RT cells. It has been reported that p53 is expressed in a majority of RTs and sequence analysis of mRNA does not show any abnormality in the p53 coding region [44,45]. Therefore, understanding the role of p53 in inhibiting drug-induced apoptosis might shed light on the mechanism of drug resistance exhibited by these tumors. Since flavopiridol increased p53 levels in RT cells, which was inversely correlated to induction of apoptosis, we explored the possibility that flavopiridol induced apoptosis through specific caspases. We profiled the kinetics of induction of caspase 2, 3, 8 and 9 activities in RT cells in the presence or absence of p53 and upon treatment with flavopiridol, 4OH-Tam, or their combination.

Analysis of the activation kinetics of caspases 2, 3, 8 and 9 indicated that neither flavopiridol nor $4 \mathrm{OH}-\mathrm{Tam}$ induced caspase 8 and 9 activities in RT cells (Figure 7A and $7 \mathrm{~B}$ and Additional File 1A-C). Induction of caspases 2 and 3 was affected by treatment with flavopiridol and flavopiridol with $4 \mathrm{OH}-\mathrm{Tam}(p=0.0022$ for caspase 2 and $p .0001$ for caspase 3$)$ and was correlated to p53 levels $(p=0.0074$ for caspse 2 and $p<0.0001$ for caspase 3) (Figure 7C and 7D). Flavopiridol increased caspase 2 and 3 activity two-fold within 6 hours and abrogation of p53 allowed flavopiridol to increase caspase 2 and 3 activity four-fold in the same time (Additional File 1D and 1G). Exposure of cells to flavopiridol with $4 \mathrm{OH}-\mathrm{Tam}$ caused an overall increase in caspase 2 


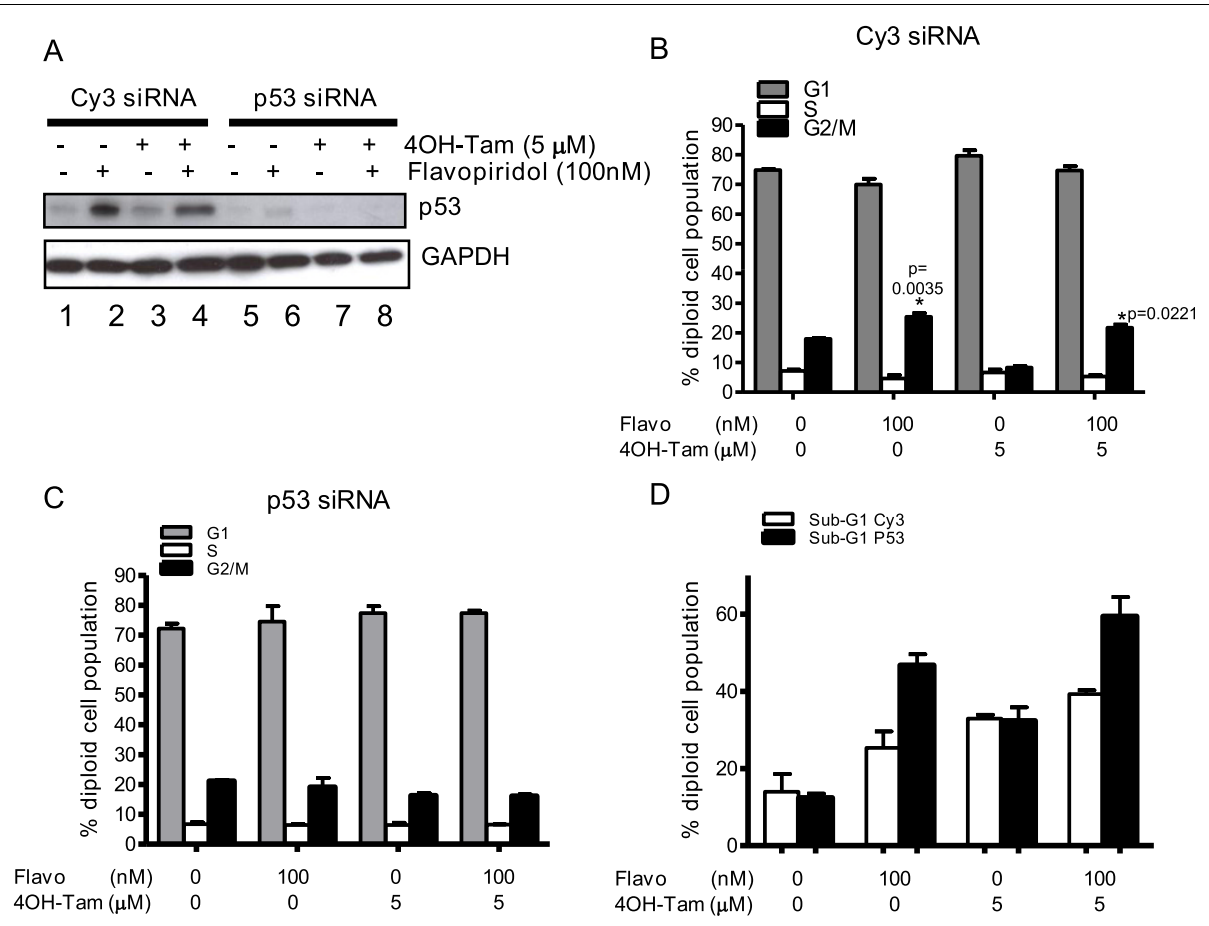

Figure 6 Effect of p53 knock-down on flavopiridol- and 4OH-Tam-induced cell cycle arrest and apoptosis: A. Immunoblot analysis to indicate siRNA mediated knock-down of p53 in MON cells treated with flavopiridol and 4OH-Tam for two days B. Percentage of diploid MON cells at various stages of cell cycle after treatment with control (Cy3) siRNA followed by treatment with flavopiridol and 4OH-Tam for two days. Note the lack of $\mathrm{G}_{\mathbf{2}}$ arrest upon drug treatment of p53-knock-down cells. C. Percentage of diploid MON cells at various stages of cell cycle after p53 knockdown (using siRNA to p53) and treatment with flavopiridol and 4OH-Tam for two days. D. Percentage of $\mathrm{MON}$ cells in sub-G $\mathbf{G}_{1}$ after transfection with control (Cy3) or p53 siRNAs and exposed to flavopiridol and 4OH-Tam for two days.

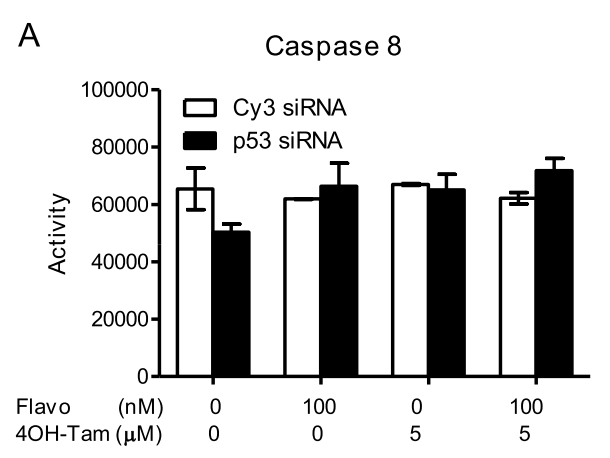

C

Caspase 2

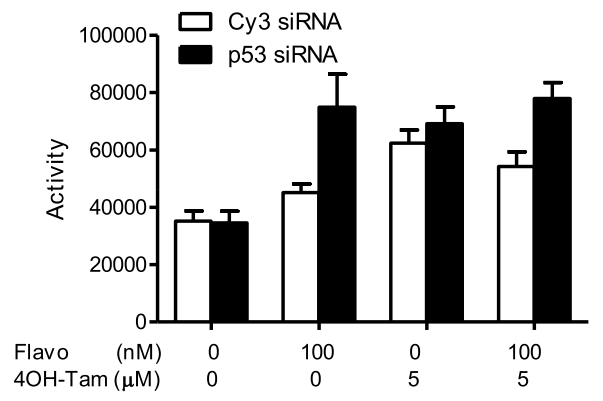

B

Caspase 9

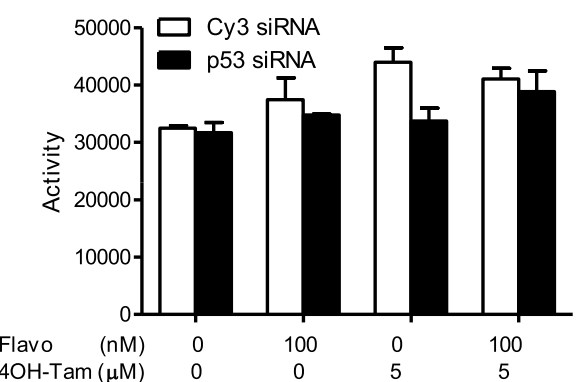

$\mathrm{D}$

Caspase 3

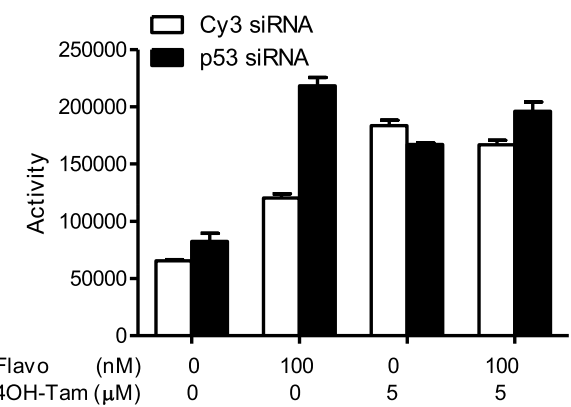

Figure 7 Flavopiridol- and $\mathbf{4 O H}$-Tam-induced caspase profiles in MON cells. A-D. Induction of caspase 8 (A), 9 (B), 2 (C), and 3 (D) activities after 24 hrs of treatment with flavopiridol, 4OH-Tam, or the combination and treated with either control (Cy3) or p53 siRNA. 
and 3 activity, with maximum induction observed at 12 hours (Figure 7C and Additional File $1 \mathrm{~F}$ and $1 \mathrm{I}$ ). Abrogation of p53 led to a further increase in caspase 2 and 3 activity after combination treatment, similar to that caused by flavopiridol alone (Figure $7 \mathrm{C}$ and Additional File $1 \mathrm{~F}$ and $1 \mathrm{I}$ ). 4OH-Tam alone caused only slight increases in caspase 2 and 3 activities in the presence or absence of p53 (Figure 7C and Additional File 1E and $1 \mathrm{H})$.

To demonstrate that induction of caspase 2 and 3 activities were specific, we treated MON cells in the presence and absence of p53 and also in the presence and absence of specific caspase 2 or 3 inhibitors. Caspase 2 and 3 activities were determined at the $24 \mathrm{hr}$. time point in all of the treatment conditions. We found that treatment of cells with caspase 2 or caspase 3 inhibitors significantly reduced the induction of caspase 2 or 3 activities upon drug treatment respectively. These results indicated that flavopiridol and $4 \mathrm{OH}$-Tam drug treatment selectively induces caspases 2 and 3 in MON cells, as inhibitors to these caspases eliminated these increases (Additional File 1J and $1 \mathrm{~K})$.

\section{Conclusions}

Our report demonstrates, for the first time, that RT cell growth and survival is potently inhibited by combination treatment with clinically achievable concentrations of $4 \mathrm{OH}-\mathrm{Tam}(2.5$ or $5 \mu \mathrm{M})$ and flavopiridol (<200 nM). Since high concentrations of flavopiridol may cause significant toxicities, and since only low concentrations may be achievable in areas such as the brain due to the blood brain barrier, our results provide a method to increase the efficacy of low concentrations of flavopiridol.

Flavopiridol and 4OH-Tam together induce a significant increase in RT cell death. Induction of cell death by flavopiridol and the combination of flavopiridol with 4OH-Tam is due to caspase-dependent apoptosis and caspase-profiling assays indicate that these treatments can potently induce caspases 2 and 3 . In addition to inducing cell death, these treatments also induce cell cycle arrest. While our previous report indicated that $400 \mathrm{nM}$ flavopiridol induces $\mathrm{G}_{1}$ arrest [13], this current report indicates that $100 \mathrm{nM}$ flavopiridol is sufficient to cause $G_{2}$ arrest indicating that flavopiridol potently induces cell cycle arrest in a dose-dependent manner. Flavopiridol-induced $\mathrm{G}_{2}$ arrest was correlated to downregulation of cyclin $\mathrm{B} 1$ and up-regulation of p53 and p $21^{\text {Waf- } 1}$. On the contrary, $4 \mathrm{OH}-\mathrm{Tam}$ inhibited $\mathrm{p} 53$ expression; however, this effect was nullified by addition of $100 \mathrm{nM}$ flavopiridol, explaining the dominant effect of flavopiridol in mediating $G_{2}$ arrest. These results suggest that the effect of flavopiridol in inducing p53 is upstream of the mechanism by which $4 \mathrm{OH}$-Tam inhibits p53.

Interestingly, we found that p53 differentially regulated flavopiridol-mediated cell cycle arrest and apoptosis. RNA interference analysis of p53 indicated that while flavopiridol-mediated $G_{2}$ arrest was dependent on p53, flavopiridol-mediated apoptosis (but not that mediated by $4 \mathrm{OH}-\mathrm{Tam}$ ) was countered by $\mathrm{p} 53$. This is an intriguing observation since there was a clear enhancement of apoptosis induced by flavopiridol when p53 was abrogated by RNA interference (Figure 6D). Previously it has been reported that lack of p53 enhances radio-sensitivity via activation of E2F-1 and induction of caspase 8 activity in glioma cells [40]. Furthermore, radio-sensitivity of keratinocytes was enhanced by abrogation of p53 and was mediated by down-regulation of anti-apoptotic proteins $\mathrm{Mcl}-1$ and $\mathrm{Bcl}_{-\mathrm{XL}}$ [41]. To our knowledge, this is the first report which indicates that down-modulation of p53 also enhances drug-induced apoptosis. Our results indicate that the potency of flavopiridol can be enhanced if p53 can be inhibited by some means.

Most RTs express p53, though a percentage of RTs do show mutations within the p53 gene [44-46]. Some RT cell lines express p53 at high levels or with increased nuclear distribution, however, the $\mathrm{p} 53$ pathway has been tested and considered to be functionally intact $[42,44]$. The mutation status of p53 in MON RT cells has not been determined but the proper expression of p53 and responsiveness of $\mathrm{p} 21^{\mathrm{Waf} 1}$ to $\mathrm{p} 53$ levels leads us to believe that the p53 pathway is intact in these cells. However, other studies indicated that the pro-apoptotic pathway downstream of p53 may be dysfunctional in MON cells but the exact nature of this defect is unknown [43]. Although this defect in the pro-apoptotic pathway downstream of p53 could account for the observed effects reported here, our observation indicates that flavopiridol-induced apoptosis is inhibited by $\mathrm{p} 53$. More experiments are needed to delineate the exact role of the p53 pathway in flavopiridol-induced cytotoxicity in MON and other RT cells.

The relationship of flavopiridol and p53 in inducing apoptosis seems to be paradoxical in different cell lines and in different treatment approaches. Perhaps this is related to the paradoxical anti-apoptotic activities of p53 itself in various cancer cells [47]. The activities of p53 are cell type dependent and can be either pro-apoptotic and/or pro-survival. For example, in RT cells p53 is deleterious to flavopiridol-mediated apoptosis, but in other cancer cell lines flavopiridol-induced apoptosis is actually dependent on p53. An example is provided by Ambrosini et al who demonstrated that enhanced apoptosis induced by a combination therapy of flavopiridol with a $\mathrm{G}_{1}$-arrest-inducing agent (namely $\mathrm{SN}$-38) was 
dependent on p53 [48]. In this study the combination of flavopiridol and SN-38 was tested on isogenic pairs of cells differing only in p53. They found that the enhanced apoptosis by combination of flavopiridol and $\mathrm{SN}-38$ was observed only in $\mathrm{p} 53^{+/+}$cells. Similar to SN$38,4 \mathrm{OH}-\mathrm{Tam}$ also induces $\mathrm{G}_{1}$ arrest in our system, however; the effects of combining flavopiridol with 4OH-Tam obtained in RT cells are different in terms of inducing apoptosis. While flavopiridol-mediated $\mathrm{G}_{2}$ arrest was dependent on p53, flavopiridol-induced apoptosis was abrogated by p53 (Figure 6C and 6D). On the contrary, p53 had no effect on 4OH-Tam-mediated apoptosis. Because of these results, we believe that p53 has compromising effects on flavopiridol-induced apoptosis in RT cells, similar to the effect of p53 in protecting cells from radiation induced apoptosis as discussed above.

Our studies involving p53 knock-down indicate that stimulation of $\mathrm{p} 53$ by flavopiridol limits its ability to induce apoptosis in RT cells. Thus, it is possible that $4 \mathrm{OH}-\mathrm{Tam}$ increases the effects of flavopiridol because it down-modulates p53 in addition to inducing apoptosis by p53-independent mechanisms. This new understanding of p53's role in drug-induced apoptosis in RT cells might shed light on the mechanism of resistance to therapies exhibited by these tumors. Also, evaluation of p53 levels induced by flavopiridol and other treatments may be necessary to implement effective treatment strategies for RTs.

Flavopiridol induces apoptosis by additional p53-independent mechanisms. It is able to block RNA polymerase II phosphorylation by inhibiting cdk 9, thereby blocking transcriptional elongation. This activity, as well as flavopiridol's ability to reduce antiapoptotic protein MCL-1, has been implicated in the induction of apoptosis in multiple myeloma cell lines [49]. Additionally, induction of the mitochondrial permeability transition by flavopiridol has been correlated with induction of apoptosis in chronic lymphocytic leukemia cells [50]. These functions of flavopiridol may also contribute to the apoptosis occurring in RT cells in a p53-independent manner.

RTs are notoriously resistant to therapeutic interventions [3]. Potent chemotherapy in combination with surgery and radiotherapy have proven futile in increasing survival rates and only a handful of RT survivors have been reported [2]. Therefore, efforts to develop molecularly targeted therapies are needed. Based on the molecular understanding of RTs, it is known that INI1/ hSNF5 mediates tumor suppression in part by targeting cyclins and cdks [7-9]. Furthermore, cyclin D1 is upregulated in, and necessary for, rhabdoid tumorigenesis $[9,12]$. Thus, it appears that therapeutically inhibiting the cyclin/cdk pathway is a novel, targeted treatment strategy for RTs. Our report suggests that combination of flavopiridol and $4 \mathrm{OH}-\mathrm{Tam}$ could be used as a novel combination therapy for RTs. Furthermore, this combination could be effective in inducing apoptosis in other tumor models, especially those lacking p53.

At this point, the concentrations of $4 \mathrm{OH}-\mathrm{Tam}$ required to increase the effects of flavopiridol appear to be high. Nevertheless, in the pediatric population, where RTs most often occur, it has been reported that high doses of tamoxifen $\left(100 \mathrm{mg} / \mathrm{m}^{2}\right.$ twice a day) can be administered with minimal toxicity [51]. Furthermore, in cases where sustained high concentrations $(\geq 10 \mathrm{uM})$ of $4 \mathrm{OH}-\mathrm{Tam}$ may not be attained, alternative formulations, such as a liposomal formulation, of both tamoxifen and $4 \mathrm{OH}-\mathrm{Tam}$ have been used that would result in the delivery of high concentrations directly to the tumor [52]. Therefore, further preclinical and clinical studies to test the efficacy of these drugs in children may lead to the development of definitive therapeutic strategies against RTs that may improve prognosis.

\section{Additional material}

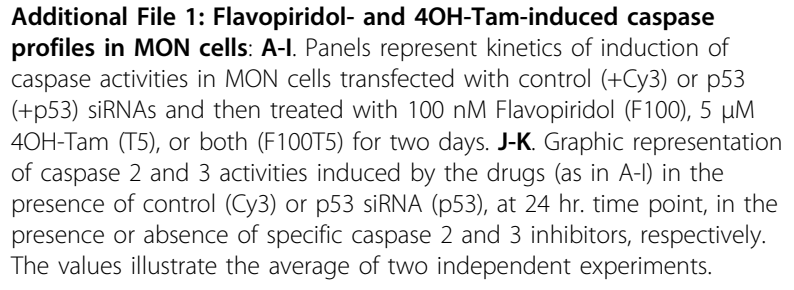

\section{Acknowledgements}

The authors thank Dr. Prasad at AECOM for critically reading the manuscript and Dr. Kitsis at AECOM for useful discussions, Dr. Colevas at CTEP, NCI for providing flavopiridol. This work was supported by grants from ACS (\#CCG10493) and Children's Brain Tumor Foundation (CBTF, NY) to G.V.K, who is a Mark Trauner faculty scholar and a recipient of the Irma T. Hirschl Career Scientist Award. M.E.S. is supported by Institutional training grant, NIGMS (T32 GM 07491).

\section{Author details}

${ }^{1}$ Department of Genetics, Albert Einstein College of Medicine, 1300 Morris Park Avenue, Bronx, New York 10461 USA. ²Department of Medicine, Albert Einstein College of Medicine, 1300 Morris Park Avenue, Bronx, New York 10461 USA. ${ }^{3}$ Albert Einstein Cancer Center, Albert Einstein College of Medicine, 1300 Morris Park Avenue, Bronx, New York 10461 USA.

\section{Authors' contributions}

VC carried out FACS analysis, most of the immunoblot analysis, caspase profiling, p53 and p21 analysis, as well as participated in the design of the study, analyzed and interpreted the data, and participated in the initial preparation of the manuscript. MES participated in the design of the study, analyzed and interpreted part of the data, drafted the manuscript, carried out cell survival assays, and part of the immunoblot analysis. ZZ initiated the studies on the treatment of rhabdoid tumor cells with combination of

flavopiridol and $4 \mathrm{OH}$-Tamoxifen in the laboratory. DM participated in part of the survival assay, SM participated in the design of the study, provided guidance in the initial part of the study and preparation of the manuscript. GVK conceived of the study, designed the experiments, analyzed and 
interpreted the data, prepared the manuscript, and provided guidance for the entire study. All authors read and approved the final manuscript.

\section{Competing interests}

The authors declare that they have no competing interests.

Received: 11 November 2009 Accepted: 19 November 2010 Published: 19 November 2010

\section{References}

1. Biegel JA: Molecular genetics of atypical teratoid/rhabdoid tumor. Neurosurg Focus 2006, 20(1):E11.

2. Reddy AT: Atypical teratoid/rhabdoid tumors of the central nervous system. J Neurooncol 2005, 75(3):309-313.

3. Strother D: Atypical teratoid rhabdoid tumors of childhood: diagnosis, treatment and challenges. Expert Rev Anticancer Ther 2005, 5(5):907-915.

4. Tekautz TM, Fuller CE, Blaney S, Fouladi M, Broniscer A, Merchant TE, Krasin M, Dalton J, Hale G, Kun LE, et al: Atypical teratoid/rhabdoid tumors (ATRT): improved survival in children 3 years of age and older with radiation therapy and high-dose alkylator-based chemotherapy. J Clin Oncol 2005, 23(7):1491-1499.

5. Biegel JA, Zhou JY, Rorke LB, Stenstrom C, Wainwright LM, Fogelgren B: Germ-line and acquired mutations of INI1 in atypical teratoid and rhabdoid tumors. Cancer Res 1999, 59(1):74-79.

6. Versteege I, Sevenet N, Lange J, Rousseau-Merck MF, Ambros P, Handgretinger R, Aurias A, Delattre O: Truncating mutations of hSNF5/INI1 in aggressive paediatric cancer. Nature 1998, 394(6689):203-206.

7. Betz BL, Strobeck MW, Reisman DN, Knudsen ES, Weissman BE: Reexpression of hSNF5/INI1/BAF47 in pediatric tumor cells leads to G1 arrest associated with induction of p16ink4a and activation of RB. Oncogene 2002, 21(34):5193-5203.

8. Versteege I, Medjkane S, Rouillard D, Delattre O: A key role of the hSNF5/ INI1 tumour suppressor in the control of the G1-S transition of the cell cycle. Oncogene 2002, 21(42):6403-6412.

9. Zhang ZK, Davies KP, Allen J, Zhu L, Pestell RG, Zagzag D, Kalpana GV: Cell cycle arrest and repression of cyclin D1 transcription by INI1/hSNF5. Mol Cell Biol 2002, 22(16):5975-5988.

10. Chai J, Charboneau AL, Betz BL, Weissman BE: Loss of the hSNF5 gene concomitantly inactivates p21CIP/WAF1 and p16INK4a activity associated with replicative senescence in A204 rhabdoid tumor cells. Cancer Res 2005, 65(22):10192-10198.

11. Alarcon-Vargas D, Zhang Z, Agarwal B, Challagulla K, Mani S, Kalpana GV: Targeting cyclin D1, a downstream effector of INI1/hSNF5, in rhabdoid tumors. Oncogene 2006, 25(5):722-734.

12. Tsikitis M, Zhang Z, Edelman W, Zagzag D, Kalpana GV: Genetic ablation of Cyclin D1 abrogates genesis of rhabdoid tumors resulting from Ini1 loss. Proc Natl Acad Sci USA 2005, 102(34):12129-12134.

13. Smith ME, Cimica V, Chinni S, Challagulla K, Mani S, Kalpana GV: Rhabdoid tumor growth is inhibited by flavopiridol. Clin Cancer Res 2008, 14(2):523-532.

14. Byrd JC, Lin TS, Dalton JT, Wu D, Phelps MA, Fischer B, Moran M, Blum KA Rovin B, Brooker-McEldowney $M$, et al: Flavopiridol administered using a pharmacologically derived schedule is associated with marked clinical efficacy in refractory, genetically high-risk chronic lymphocytic leukemia. Blood 2007, 109(2):399-404.

15. Whitlock JA, Krailo M, Reid JM, Ruben SL, Ames MM, Owen W, Reaman G: Phase I clinical and pharmacokinetic study of flavopiridol in children with refractory solid tumors: a Children's Oncology Group Study. J Clin Oncol 2005, 23(36):9179-9186.

16. Carlson B, Lahusen T, Singh S, Loaiza-Perez A, Worland PJ, Pestell R, Albanese C, Sausville EA, Senderowicz AM: Down-regulation of cyclin D1 by transcriptional repression in MCF-7 human breast carcinoma cells induced by flavopiridol. Cancer Res 1999, 59(18):4634-4641.

17. Chao SH, Price DH: Flavopiridol inactivates P-TEFb and blocks most RNA polymerase II transcription in vivo. J Biol Chem 2001, 276(34):31793-31799.

18. Chao SH, Fujinaga K, Marion JE, Taube R, Sausville EA, Senderowicz AM, Peterlin BM, Price DH: Flavopiridol inhibits P-TEFb and blocks HIV-1 replication. J Biol Chem 2000, 275(37):28345-28348.

19. de Azevedo WF Jr, Canduri F, da Silveira NJ: Structural basis for inhibition of cyclin-dependent kinase 9 by flavopiridol. Biochem Biophys Res Commun 2002, 293(1):566-571.
20. Takada Y, Aggarwal BB: Flavopiridol inhibits NF-kappaB activation induced by various carcinogens and inflammatory agents through inhibition of IkappaBalpha kinase and p65 phosphorylation: abrogation of cyclin D1, cyclooxygenase-2, and matrix metalloprotease-9. J Biol Chem 2004, 279(6):4750-4759.

21. Cappellini A, Tabellini G, Zweyer M, Bortul R, Tazzari PL, Billi AM, Fala F, Cocco L, Martelli AM: The phosphoinositide 3-kinase/Akt pathway regulates cell cycle progression of HL60 human leukemia cells through cytoplasmic relocalization of the cyclin-dependent kinase inhibitor p27 (Kip1) and control of cyclin D1 expression. Leukemia 2003, 17(11):2157-2167.

22. Liang J, Slingerland JM: Multiple roles of the PI3K/PKB (Akt) pathway in cell cycle progression. Cell Cycle 2003, 2(4):339-345.

23. Schmidt M, Fernandez de Mattos S, van der Horst A, Klompmaker R Kops GJ, Lam EW, Burgering BM, Medema RH: Cell cycle inhibition by FoxO forkhead transcription factors involves downregulation of cyclin D. Mol Cell Biol 2002, 22(22):7842-7852.

24. Wu K, Wang C, D'Amico M, Lee RJ, Albanese C, Pestell RG, Mani S: Flavopiridol and trastuzumab synergistically inhibit proliferation of breast cancer cells: association with selective cooperative inhibition of cyclin D1-dependent kinase and Akt signaling pathways. Mol Cancer Ther 2002, 1(9):695-706.

25. Sedlacek HH: Mechanisms of action of flavopiridol. Crit Rev Oncol Hematol 2001, 38(2):139-170.

26. Demidenko ZN, Blagosklonny MV: Flavopiridol induces p53 via initial inhibition of Mdm2 and p21 and, independently of p53, sensitizes apoptosis-reluctant cells to tumor necrosis factor. Cancer Res 2004, 64(10):3653-3660.

27. Puppo M, Pastorino S, Melillo G, Pezzolo A, Varesio L, Bosco MC: Induction of apoptosis by flavopiridol in human neuroblastoma cells is enhanced under hypoxia and associated with $\mathrm{N}$-myc proto-oncogene downregulation. Clin Cancer Res 2004, 10(24):8704-8719.

28. Newcomb EW, Tamasdan C, Entzminger Y, Alonso J, Friedlander D, Crisan D, Miller DC, Zagzag D: Flavopiridol induces mitochondrialmediated apoptosis in murine glioma GL261 cells via release of cytochrome $\mathrm{c}$ and apoptosis inducing factor. Cell Cycle 2003, 2(3):243-250.

29. Fornier MN, Rathkopf D, Shah M, Patil S, O'Reilly E, Tse AN, Hudis C, Lefkowitz R, Kelsen DP, Schwartz GK: Phase I dose-finding study of weekly docetaxel followed by flavopiridol for patients with advanced solid tumors. Clin Cancer Res 2007, 13(19):5841-5846.

30. Karp JE, Smith BD, Levis MJ, Gore SD, Greer J, Hattenburg C, Briel J, Jones RJ, Wright JJ, Colevas AD: Sequential flavopiridol, cytosine arabinoside, and mitoxantrone: a phase II trial in adults with poor-risk acute myelogenous leukemia. Clin Cancer Res 2007, 13(15 Pt 1):4467-4473.

31. Stendahl M, Kronblad AA, Ryden L, Emdin S, Bengtsson NO, Landberg G: Cyclin D1 overexpression is a negative predictive factor for tamoxifen response in postmenopausal breast cancer patients. $\mathrm{Br} J$ Cancer 2004, 90(10):1942-1948.

32. Christov KT, Shilkaitis AL, Kim ES, Steele VE, Lubet RA: Chemopreventive agents induce a senescence-like phenotype in rat mammary tumours. Eur J Cancer 2003, 39(2):230-239.

33. Han S, Park K, Bae BN, Kim KH, Kim HJ, Kim YD, Kim HY: Cyclin D1 expression and patient outcome after tamoxifen therapy in estrogen receptor positive metastatic breast cancer. Oncol Rep 2003, 10(1):141-144.

34. Kenny FS, Hui R, Musgrove EA, Gee JM, Blamey RW, Nicholson Rl, Sutherland RL, Robertson JF: Overexpression of cyclin D1 messenger RNA predicts for poor prognosis in estrogen receptor-positive breast cancer. Clin Cancer Res 1999, 5(8):2069-2076.

35. Jang TJ, Park JH, Cho MY, Kim JR: Chemically induced rat mammary tumor treated with tamoxifen showed decreased expression of cyclin D1, cyclin E, and p21(Cip1). Cancer Lett 2001, 170(2):109-116.

36. Lee TH, Chuang LY, Hung WC: Tamoxifen induces p21WAF1 and p27KIP1 expression in estrogen receptor-negative lung cancer cells. Oncogene 1999, 18(29):4269-4274.

37. Koshida S, Narita T, Kato H, Yoshida S, Taga T, Ohta S, Takeuchi Y: Estrogen receptor expression and estrogen receptor-independent cytotoxic effects of tamoxifen on malignant rhabdoid tumor cells in vitro. Jpn J Cancer Res 2002, 93(12):1351-1357.

38. Bunz F, Dutriaux A, Lengauer C, Waldman T, Zhou S, Brown JP, Sedivy JM, Kinzler KW, Vogelstein B: Requirement for $\mathrm{p} 53$ and p21 to sustain G2 arrest after DNA damage. Science 1998, 282(5393):1497-1501. 
39. Isakoff MS, Sansam CG, Tamayo P, Subramanian A, Evans JA, Fillmore CM, Wang X, Biegel JA, Pomeroy SL, Mesirov JP, et al: Inactivation of the Snf5 tumor suppressor stimulates cell cycle progression and cooperates with p53 loss in oncogenic transformation. Proc Natl Acad Sci USA 2005, 102(49): 17745-17750.

40. Afshar G, Jelluma N, Yang X, Basila D, Arvold ND, Karlsson A, Yount GL, Dansen TB, Koller E, Haas-Kogan DA: Radiation-induced caspase-8 mediates p53-independent apoptosis in glioma cells. Cancer Res 2006, 66(8):4223-4232

41. Chaturvedi V, Sitailo LA, Qin JZ, Bodner B, Denning MF, Curry J, Zhang W, Brash D, Nickoloff BJ: Knockdown of p53 levels in human keratinocytes accelerates Mcl-1 and Bcl-x(L) reduction thereby enhancing UV-light induced apoptosis. Oncogene 2005, 24(34):5299-5312.

42. Rosson GB, Vincent TS, Oswald BW, Wright CF: Drug resistance in malignant rhabdoid tumor cell lines. Cancer Chemother Pharmacol 2002, 49(2):142-148.

43. Nocentini S: Apoptotic response of malignant rhabdoid tumor cells. Cancer Cell Int 2003, 15:11.

44. Rosson GB, Hazen-Martin DJ, Biegel JA, Willingham MC, Garvin AJ, Oswald BW, Wainwright L, Brownlee NA, Wright CF: Establishment and molecular characterization of five cell lines derived from renal and extrarenal malignant rhabdoid tumors. Mod Pathol 1998, 11(12):1228-1237.

45. Kaiserling E, Ruck P, Handgretinger R, Leipoldt M, Hipfel R: Immunohistochemical and cytogenetic findings in malignant rhabdoid tumor. Gen Diagn Pathol 1996, 141(5-6):327-337.

46. Kinoshita Y, Tamiya S, Oda Y, Mimori K, Inoue H, Ohta S, Tajiri T, Suita S, Tsuneyoshi M: Establishment and characterization of malignant rhabdoid tumor of the kidney. Oncol Rep 2001, 8(1):43-48.

47. Janicke RU, Sohn D, Schulze-Osthoff K: The dark side of a tumor suppressor: anti-apoptotic p53. Cell Death Differ 2008, 15(6):959-976.

48. Ambrosini G, Seelman SL, Qin LX, Schwartz GK: The cyclin-dependent kinase inhibitor flavopiridol potentiates the effects of topoisomerase I poisons by suppressing Rad51 expression in a p53-dependent manner. Cancer Res 2008, 68(7):2312-2320.

49. Gojo I, Zhang B, Fenton RG: The cyclin-dependent kinase inhibitor flavopiridol induces apoptosis in multiple myeloma cells through transcriptional repression and down-regulation of Mcl-1. Clin Cancer Res 2002, 8(11):3527-3538.

50. Hussain SR, Lucas DM, Johnson AJ, Lin TS, Bakaletz AP, Dang VX, Viatchenko-Karpinski S, Ruppert AS, Byrd JC, Kuppusamy P, et al: Flavopiridol causes early mitochondrial damage in chronic lymphocytic leukemia cells with impaired oxygen consumption and mobilization of intracellular calcium. Blood 2008, 111(6):3190-3199.

51. Pollack IF, DaRosso RC, Robertson PL, Jakacki RL, Mirro JR Jr, Blatt J, Nicholson S, Packer RJ, Allen JC, Cisneros A, et al: A phase I study of highdose tamoxifen for the treatment of refractory malignant gliomas of childhood. Clin Cancer Res 1997, 3(7):1109-1115.

52. Zeisig R, Teppke AD, Behrens D, Fichtner I: Liposomal 4-hydroxytamoxifen: effect on cellular uptake and resulting cytotoxicity in drug resistant breast cancer cells in vitro. Breast Cancer Res Treat 2004, 87(3):245-254.

\section{Pre-publication history}

The pre-publication history for this paper can be accessed here: http://www.biomedcentral.com/1471-2407/10/634/prepub

doi:10.1186/1471-2407-10-634

Cite this article as: Cimica et al:: Potent inhibition of rhabdoid tumor cells by combination of flavopiridol and $4 \mathrm{OH}$-tamoxifen. BMC Cancer 2010 10:634.

\section{Submit your next manuscript to BioMed Central and take full advantage of:}

- Convenient online submission

- Thorough peer review

- No space constraints or color figure charges

- Immediate publication on acceptance

- Inclusion in PubMed, CAS, Scopus and Google Scholar

- Research which is freely available for redistribution

Submit your manuscript at www.biomedcentral.com/submit
C Biomed Central 